\title{
EFEKTIFITAS PEMANFAATAN TANAMAN SEBAGAI INSEKTISIDA ELEKTRIK UNTUK MENGENDALIKAN NYAMUK PENULAR PENYAKIT DBD
}

\author{
Aseptianova ${ }^{1}$, Tutik Fitri Wijayanti ${ }^{2}$, Nita Nuraini ${ }^{\underline{3}}$ \\ Universitas Muhammadiyah Palembang \\ E-mail: nasepti@yahoo.co.id
}

\begin{abstract}
The use of anti-mosquito with chemical materials widely used along with increasing mosquito population to dengue fever (DBD). Prevention of mosquito by utilizing natural ingredients into one alternative that is not only beneficial for humans but also the surrounding environment. The research objective was to determine the effectiveness of mint leaves, galangal, Sambiloto, babadotan, avocado leaves, bay leaves, shoots red, and leaves zodia as anti mosquito electrically against Aedes ae-gypti, research procedures conducted using a completely randomized design (RAL) with 8 independent variables (8 plants) and one dependent variable (Aedes aegypti). Number of treatment as much as 9 with three replications. Based on this research can be seen that within 5 minutes, the extract is most effective for her mortality-muk is the avocado leaf extract and leaf Salam as much as $100 \%$, ginger extract as much as $82.22 \%$, Mint leaf extract as much as $51.11 \%$, and babadotan leaf extract as much as $8.89 \%$. Based on the results of over 60 minutes, the result that the mosquitoes were diu-jicobakan death with a mortality rate that is different for each extract. Bay leaf extract and avocado leaves are able to kill mosquitoes within 5 minutes, ginger and mint leaves are able to kill mosquitoes within 10 minutes by a percentage greater galangal. Babadotan leaf extract capable of killing mosquitoes within 20 minutes, while extracts Zodia able to kill mosquitoes within 30 minutes (the 25th minute and the 30th minute). Mosquitoes faster die are male mosquitoes. The analysis showed a significance of $(0,00)<0.05$, which means that the plant extract air-significant effect on mortality of Aedes aegypti L.
\end{abstract}

Keywords: Botanical Insecticides, Insecticide Electric, Dengue, Aedes aegypti L.

\begin{abstract}
Abstrak: Penggunaan obat anti nyamuk berbahan dasar kimia marak dilakukan seiring meningkatnya populasi nyamuk demam berdarah (DBD). Pencegahan nyamuk dengan memanfaatkan bahan alami menjadi salah satu alternatif yang tidak hanya menguntungkan bagi manusia tapi juga lingkungan sekitar. Tujuan penelitian adalah untuk mengetahui efektifitas daun mint, lengkuas, Sambiloto, babadotan, daun alpukat, daun salam, pucuk merah, dan daun zodia sebagai obat anti nyamuk elektrik terhadap nyamuk Aedes aegypti. Prosedur penelitian dilakukan menggunakan metode rancangan acak lengkap (RAL) dengan 8 variabel bebas ( 8 tanaman) dan 1 variabel terikat (nyamuk Aedes aegypti). Jumlah perlakuan sebanyak 9 dengan 3 kali ulangan. Berdasarkan penelitian yang dilakukan dapat diketahui bahwa dalam waktu 5 menit, ekstrak yang paling efektif untuk mortalitas nyamuk adalah pada ekstrak daun Alpukat dan daun Salam sebanyak $100 \%$, ekstrak lengkuas sebanyak $82,22 \%$, esktrak daun Mint sebanyak $51,11 \%$, dan ekstrak daun Babadotan sebanyak 8,89\%. Ekstrak daun salam dan daun alpukat mampu membunuh nyamuk dalam waktu 5 menit, lengkuas dan daun mint mampu membunuh nyamuk dalam waktu 10 menit dengan persentase lengkuas yang lebih besar. Ekstrak daun Babadotan mampu membunuh nyamuk dalam waktu 20 menit, sedangkan ekstrak Zodia mampu membunuh nyamuk dalam waktu 30 menit (perhitungan menit ke-25 dan menit ke-30). Hasil analisis menunjukkan signifikansi sebesar $(0,00)<0,05$ yang berarti ekstrak tanaman berpengaruh nyata terhadap mortalitas nyamuk Aedes aegypti L.
\end{abstract}

Kata kunci: Insektisida Botani, Insektisida Elektrik, DBD, Aedes aegypti L.

\section{PENDAHULUAN}

Penyakit Demam Berdarah Dengue (DBD) merupakan penyakit endemis yang banyak ditemui di Indonesia setiap tahunnya. Penyakit ini disebabkan oleh gigitan nyamuk Aedes aegypti L. dengan membawa virus dengue pada tiap gigitan. Demam Berdarah Dengue(DBD) merupakan salah satu masalah kesehatan bagi 
masyarakat yang cenderung meningkat jumlah penderitanya dan semakin luas daerah penyebarannya, sejalan dengan meningkatnya mobilitas dan kepadatan penduduk (Depkes RI, 1995). Upaya pencegahan sangat diperlukan untuk mencegah penyebaran nyamuk Aedes aegypti L. yang merupakan faktor utama penyebab DBD.

Budiasih (2011) menyatakan bahwa nyamuk umumnya banyak bersarang di lingkungan yang lembab, dingin dan gelap, untuk itu perlu adanya pencegahan secara dini mulai dari diri sendiri hingga lingkungan sekitar seperti pengaturan sirkulasi udara dan pencahayaan yang baik, mengurangi potensi tempattempat gelap sebagai sarang nyamuk, menghilangkan genangan air yang bisa jadi tempat berkembang biak dan pemanfaatan tanaman-tanaman yang ada di sekitar kita sebagai larvasida alami yang mampu mengusir nyamuk demam berdarah.

Masyarakat di Indonesia cenderung terbiasa menggunakan obat anti nyamuk berbahan kimia yang beredar di pasaran sebagai salah satu cara untuk mengusir dan mencegah berkembangnya nyamuk Aedes aegypti. Obat anti nyamuk berbahan kimia umumnya mengandung zat fumigan, DEET, Piretroid, propoksur, dan lain-lain. Kandungan tersebut sangat berbahaya karena dapat menimbulkan efek toksik baik lokal maupun sistemik terhadap manusia. Efek lokal pada umumnya melalui pajanan dermal, sedangkan efek sistemik melalui pajanan oral dan inhalasi (Raini, 2009). Penggunaan obat nyamuk dengan bahan kima tidak hanya merugikan bagi kesehatan manusia, akan tetapi juga dapat menyebabkan resistensi terhadap nyamuk itu sendiri (Rahman \& Sofiana, 2016). Pengurangan dampak negatif penggunaan bahan-bahan kimia tersebut dapat diatasi dengan memanfaatkan bahan-bahan alami yang ada di sekitar kita, seperti tanaman.

Pemanfaatan tanaman untuk mengusirnyamukinilebih dikenal dengan istilah insektisida nabati. Insektisida nabati atau alami menggunakan bahan dasar tumbuhan sehingga bersifat mudah terurai (bio-degradable) di alam, tidak mencemari lingkungan dan relatif aman bagi manusia dan ternak peliharaan, karena residu (sisa-sisa zat) mudah hilang. Admadi H (2009) juga menambahkan bahwa beberapa tanaman dan bagianbagian tertentunya seperti daun, bunga, biji, batang, rimpang atau umbi memiliki kandungan insektisida alami. Semua bahan yang digunakan berasal dari tumbuhan maka dapat dipastikan bahwa senyawa insektisidanya tidak akan memberikan efek samping yang negatif bagi penggunanya bila digunakan secara benar.

Permasalahan yang demikian dapat diatasi dengan memanfaatkan beberapa tanaman teridentifikasi memiliki kandungan yang mampu membantu mengusir dan mencegah penyebaran nyamuk demam berdarah. Tanamantanaman tersebut antara lain: daun mint, umbi lengkuas, sambiloto, babadotan, daun alpukat, daun salam, pucuk merah, dan daun zodia. Jenis tanaman insektisida tersebut dapat dibuat ekstraknya yang akan digunakan sebagai pengganti bahan zat kimia untuk obat anti nyamuk elektrik. Tanaman-tanaman tersebut dikenal mengandung senyawa aktif seperti flavonoid, saponin, tanin, alkaloid, dan terpenoid. Berdasarkan penelitian yang sudah dilakukan oleh Aseptianova (2015), Fitriah (2015), Harahap (2014) dan Nofyan, Marisa, \& Kamal (2012) yang menyatakan bahwa tanaman-tanaman tersebut dapat digunakan sebagai insektisida alami untuk membunuh nyamuk Aedes aegypti. 
Berdasarkan uraian di atas, penelitian ini dilakukan untuk membuktikan efektifitas beberapa tanaman tersebut sebagai insektisida elektrik dalam mengendalikan nyamuk DBD (Aedes aegypti L.).

\section{METODE PENELITIAN}

Penelitian ini menggunakan rancangan acak lengkap (RAL) dengan variabel bebas terdiri atas: ekstrak daun mint, umbi lengkuas, sambiloto, babadotan, daun alpukat, daun salam, pucuk merah, dan daun zodia, sedangkan variabel terikat yaitu mortalitas nyamuk Aedes aegypti (fase nyamuk dewasa). Terdiri dari 9 perlakuan dan 3 kali ulangan. Jumlah seluruh nyamuk adalah 405 ekor. Penelitian dilakukan di Laboratorium Biologi Fakultas Keguruan dan Ilmu Pendidikan Universitas Muhammadiyah Palembang

\section{HASIL DAN PEMBAHASAN}

\section{Deskripsi Data Hasil Penelitian}

Penelitian ini menggunakan 9 perlakuan dengan rincian: $\mathrm{P}_{0}$ (ethanol), $\mathrm{P}_{1}$ (ekstrak daun mint), $\mathrm{P}_{2}$ (ekstrak lengkuas), $\mathrm{P}_{3}$ (ekstrak sambiloto), $\mathrm{P}_{4}$ (ekstrak daun Babadotan), $P_{5}$ (ekstrak daun Alpukat), $\mathrm{P}_{6}$ (45 ml ekstrak daun Salam), $\mathrm{P}_{7}$ (ekstrak daun pucuk merah) dan $\mathrm{P}_{8}$ (ekstrak daun Zodia).

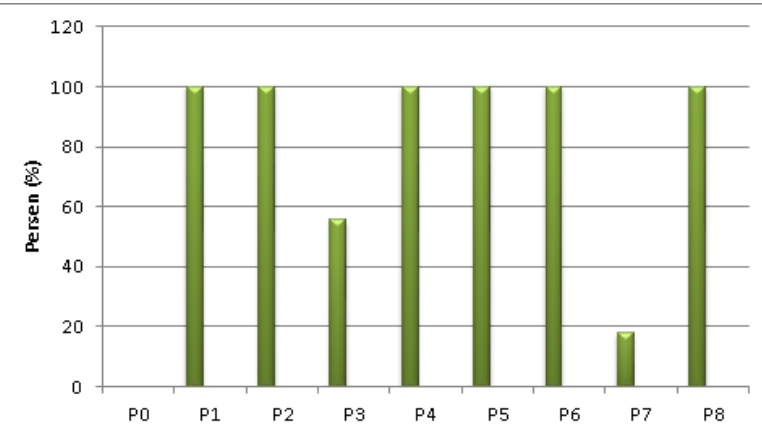

Gambar 1.1. Grafik Persentase Mortalitas Nyamuk Aedes aegypti L. terhadap Berbagai Ekstrak per 60 Menit.
Berdasarkan data dari Gambar 1.1 dapat disimpulkan bahwa jumlah mortalitas nyamuk yang tinggi berada pada perlakuan menggunakan ekstrak daun Mint, Lengkuas, daun Babadotan, daun Alpukat, daun Salam, dan daun Zodia.

Data mortalitas nyamuk per 5 menit dapat dilihat pada Gambar 1.2 berikut.

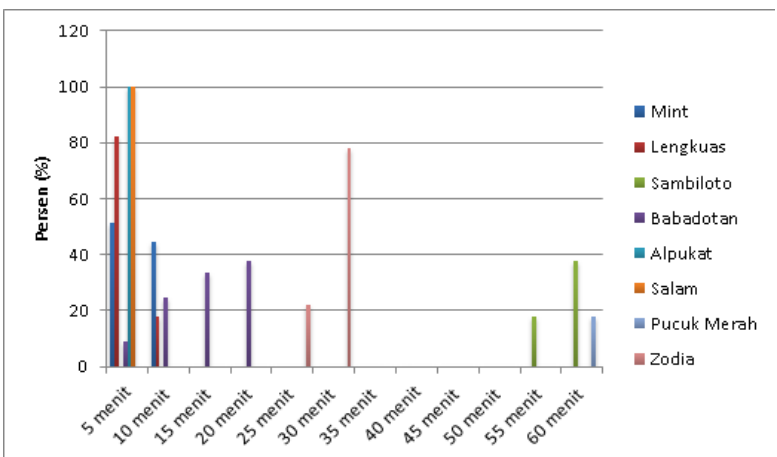

\section{Gambar 1.2 Grafik Persentase Mortalitas Nyamuk per 5 Menit.}

Hasil di atas menunjukkan bahwa dalam waktu 5 menit, ekstrak yang paling efektif untuk mortalitas nyamuk adalah ekstrak daun Alpukat dan daun Salam dengan persentase sebesar $100 \%$, ekstrak lengkuas sebesar $82,22 \%$, esktrak daun Mint sebesar 51,11\%, dan ekstrak daun Babadotan sebesar 8,89\%.

Pada pengamatan dengan kurun waktu 1 jam diperoleh data bahwa kematian nyamuk lebih banyak terjadi pada jenis kelamin betina, karena jumlah nyamuk yang digunakan lebih banyak nyamuk betina. Jumlah total nyamuk yang digunakan untuk penelitian adalah 405 ekor, dengan jumlah jantan 191 ekor sedangkan betina berjumlah 214 ekor. Untuk nyamuk yang mati selama satu jam berjumlah 303 ekor, dengan jumlah jantan yang mati 147 ekor dan betina 156 ekor. Beriku ini data perbandingan mortalitas antara nyamuk jantan dan betina. 


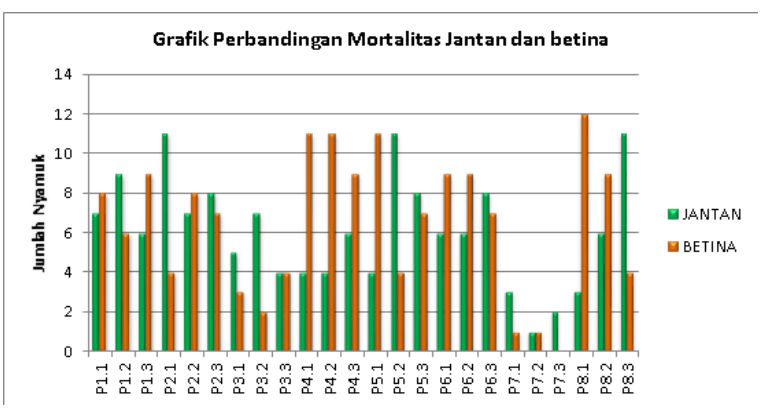

Gambar 1.3 Perbandingan Jumlah Mortalitas antara Nyamuk Jantan dan Betina.

Selama penelitian berlangsung, nyamuk yang lebih cepat mati adalah nyamuk jantan. Untuk perwakilan dapat dilihat pada ekstrak P3 (sambiloto) dan P7 (pucuk merah) yang dalam satu jam tidak mati semuanya, data yang diperoleh adalah: pada P3.1 jumlah jantan yang mati 5 ekor sedangkan betinanya 3 ekor, pada P3.2 jumlah jantan yang mati 7 ekor sedangkan betinanya 2 ekor 7, pada P3.3 jumlah jantan yang mati 4 ekor sedangkan betinanya 4 ekor, pada P7.1 jumlah jantan yang mati 3 ekor sedangkan betinanya 1 ekor, pada P7.2 jumlah jantan yang mati 1 ekor sedangkan betinanya 1 ekor, dan pada P7.3 jumlah jantan yang mati 2 ekor sedangkan betinanya 0 ekor.

\section{Pengujian Hipotesis Penelitian Pe- manfaatan Berbagai Ekstrak Tana- man sebagai Insektisida Alami \\ Melalui uji perbedaan One-Way ANOVA, ada perbedaan nilai akhir yang signifikan antara setiap ekstrak yang}

diujikan.

Tabel 1.1 Hasil Analisis Pemanfaatan Berbagai Ekstrak Tanaman sebagai Insektisida Alami

\begin{tabular}{|c|c|c|}
\hline signifikansi & Kriteria & Keputusan Uji \\
\hline $\begin{array}{l}\text { Berbagai Ekstrak } \\
\text { Tanaman }\end{array}$ & $\begin{array}{l}\text { signifikansi }< \\
0,05\end{array}$ & $\begin{array}{c}\mathrm{H}_{0} \text { Ditolak } \\
\text { Berpengaruh Sangat Nyata }\end{array}$ \\
\hline $\begin{array}{l}\text { Berdasarkan Tabel } 1.1 \text { dapat diliha } \\
\text { bahwa hasil analisis menunjukkar } \\
\text { signifikansi }<0,05 \text { maka } \mathrm{H}_{0} \text { ditolak dan } \mathrm{H} \\
\text { diterima, artinyaberbagai ekstraktanamar } \\
\text { yang digunakan (daun mint, lengkuas } \\
\text { daun sambiloto, daun babadotan, daur }\end{array}$ & \multicolumn{2}{|c|}{$\begin{array}{l}\text { alpukat, daun salam, daun pucuk merah, } \\
\text { dan daun zodia) berpengaruh terhadap } \\
\text { mortalitas nyamuk Aedes aegypti L. } \\
\text { Menggunakan uji post hoc test Tukey } \\
\text { HSD didapat hasil bahwa ada perbedaan } \\
\text { dengan signifikansi } 0,000<0,005 \text {. Masing- } \\
\text { masing ekstrak dapat dirangkum pada }\end{array}$} \\
\hline
\end{tabular}

Tabel 1.2.

Tabel 1.2 Rangkuman Hasil Post Hoc Test Tukey HSD pada Berbagai Ekstrak Tanaman.

\begin{tabular}{|c|c|c|c|c|}
\hline $\begin{array}{c}\text { Ekstrak } \\
\text { Tumbuhan (I) }\end{array}$ & $\begin{array}{c}\text { Ekstrak } \\
\text { Tumbuhan (J) }\end{array}$ & $\begin{array}{c}\text { Mean } \\
\text { Diffference }\end{array}$ & Signifikansi & Keterangan \\
\hline \multirow{2}{*}{ Mint } & Sambiloto & 6,667 & 0,000 & $\begin{array}{l}\text { Mint lebih baik dari } \\
\text { sambiloto }\end{array}$ \\
\hline & Pucuk Merah & 12,333 & 0,000 & $\begin{array}{l}\text { Mint lebih baik dari pucuk } \\
\text { merah }\end{array}$ \\
\hline \multirow{2}{*}{ Lengkuas } & Sambiloto & 6,667 & 0,000 & $\begin{array}{l}\text { Lengkuas lebih baik dari } \\
\text { sambiloto }\end{array}$ \\
\hline & Pucuk Merah & 12,333 & 0,000 & $\begin{array}{l}\text { Lengkuas lebih baik dari } \\
\text { pucuk merah }\end{array}$ \\
\hline Sambiloto & Pucuk Merah & 5,667 & 0,000 & $\begin{array}{l}\text { Sambiloto lebih baik dari } \\
\text { pucuk merah }\end{array}$ \\
\hline
\end{tabular}




\begin{tabular}{|c|c|c|c|c|}
\hline $\begin{array}{c}\text { Ekstrak } \\
\text { Tumbuhan (I) }\end{array}$ & $\begin{array}{c}\text { Ekstrak } \\
\text { Tumbuhan (J) }\end{array}$ & $\begin{array}{c}\text { Mean } \\
\text { Diffference }\end{array}$ & Signifikansi & Keterangan \\
\hline \multirow{2}{*}{ Babadotan } & Sambiloto & 6,667 & 0,000 & $\begin{array}{l}\text { Babadotan lebih baik dari } \\
\text { sambiloto }\end{array}$ \\
\hline & Pucuk Merah & 12,333 & 0,000 & $\begin{array}{l}\text { Babadotan lebih baik dari } \\
\text { pucuk merah }\end{array}$ \\
\hline \multirow{2}{*}{ Alpukat } & Sambiloto & 6,667 & 0,000 & $\begin{array}{l}\text { Alpukat lebih baik dari } \\
\text { sambiloto }\end{array}$ \\
\hline & Pucuk Merah & 12,333 & 0,000 & $\begin{array}{l}\text { Alpukat lebih baik dari } \\
\text { pucuk merah }\end{array}$ \\
\hline \multirow{2}{*}{ Salam } & Sambiloto & 6,667 & 0,000 & $\begin{array}{l}\text { Salam lebih baik dari } \\
\text { sambiloto }\end{array}$ \\
\hline & Pucuk Merah & 12,333 & 0,000 & $\begin{array}{l}\text { Salam lebih baik dari } \\
\text { pucuk merah }\end{array}$ \\
\hline \multirow{2}{*}{ Zodia } & Sambiloto & 6,667 & 0,000 & $\begin{array}{l}\text { Zodia lebih baik dari } \\
\text { sambiloto }\end{array}$ \\
\hline & Pucuk Merah & 12,333 & 0,000 & $\begin{array}{l}\text { Zodia lebih baik dari } \\
\text { pucuk merah }\end{array}$ \\
\hline
\end{tabular}

Ekstrak Mint, Lengkuas, Babadotan, Alpukat, Salam, dan Zodia dinyatakan memiliki nilai akhir yang lebih baik $(\mathrm{M}=$ $15, \mathrm{SD}=0,00)$ jika dibandingkan dengan ekstrak sambiloto $(\mathrm{M}=8,33 ; \mathrm{SD}=0,577)$ dan pucuk merah $(\mathrm{M}=2,67 ; \mathrm{SD}=1,155)$. Untuk ekstrak sambiloto dinyatakan lebih baik jika dibandingkan dengan ekstrak pucuk merah.

Etanol yang digunakan sebagai kontrol diperoleh hasil bahwa tidak ada pengaruh bagi nyamuk dan ada perbedaan dengan ekstrak tanaman yang diuji cobakan $(0,000<0,05)$. Angka Mean Difference juga menunjukkan nilai negatif terhadap ekstrak yang diujikan, artinya ekstrak tanaman yang diujicobakan lebih baik dibanding etanol.

\section{Pembahasan}

Berdasarkan Tabel 1.1 hasil analisis menyatakan signifikansi $(0,00)<0,05$ yang berarti ekstrak tanaman berpengaruh nyata terhadap mortalitas nyamuk Aedes aegypti L. Hal ini terjadi karena pada ekstrak tanaman yang digunakan yaitu daun mint, lengkuas, daun sambiloto, daun babadotan, daun alpukat, daun salam, daun pucuk merah, dan daun zodia terbukti memiliki senyawa aktif yang mampu membunuh nyamuk sebagai insektisida alami.

Sastrohamidjojo (2004) menjelaskan bahwasannya daun mint memiliki kandungan senyawa menthol dan menthone yang dapat berfungsi untuk membunuh serangga dengan cara menghambat proses sintesis protein. Lengkuas mengandung senyawa terpenoid, alkaloid, tanin, saponin, flavonoid, dan fenol yang dapat bersifat bakterisidal dan fungsidal sehingga dapat dinyatakan sebagai bioinsektisida (Riyanti, 1996; Nursal \& Siregar, 2005). Adekunle \& Ayodele (2014) menyatakan bahwa daun sambiloto mengandung senyawa flavonoid, terpenoid. Kardinan (2001) menyatakan pula jika di babadotan memiliki kandungan senyawa alkaloid, flavonoid, kumarin, saponin, polifenol, dan minyak atsiri. Charyadie, Adi, dan Sari (2014) mengungkapkan bahwa ekstrak daun alpukat mengandung senyawa aktif seperti alkaloid, flavonoid, saponin, dan tanin. Murtini \& Widodo 
(2006) menyatakan daun salam (Syzygium polyanthum) memiliki kandungan minyak atsiri $0.05 \%$ (sitral, eugenol), flavonoid, tannin, dan metachavicol. Haryati, Saleh, \& Erwin (2015) menyatakan kandungan dalam ekstrak total daun pucuk merah adalah alkaloid, triterpenoid, steroid, saponin, fenolik, dan flavonoid. Kardinan (2004) menjelaskan bahwa daun Zodia mengandung senyawa aktif linalool (46\%) dan $\alpha$-pinen (13,26\%). Boesri dkk (2015) menambahkan bahwa daun zodia memiliki bahan aktif dominan evodiamine, sedangkan lengkuas dengan bahan aktif dominan flavonoid.

Berdasarkan uraian di atas dapat disimpulkan bahwa kandungan pada ekstrak yang digunakan sebagian besar adalah flavonoid, saponin, tanin, alkaloid, dan linalool. Senyawa flavonoid diyakini mampu merusak sel bakteri dengan cara membentuk senyawa kompleks dengan protein ekstraseluler dan terlarut sehingga senyawa intraseluler akan keluar menuju ekstraseluler (Nuria, Faizatun, dan Sumantri, 2009). Ketika Flavonoid diabsorbsi, akan mengalami peningkatan fungsi biologis, diantaranya sintesis protein, diferensiasi dan proliferasi sel, serta angiogenesis. Apabila flavonoid dikomsumsi secara berlebihan, akan menyebabkan mutagen dan menghambat enzim-enzim tertentu dalam kerja metabolisme hormon serta metabolisme energi (Sabir, 2003; Cushnie, 2005). Tentunya hal ini juga berpengaruh pada serangga, dimana flavonoid akan merusak permeabilitas dinding sel dan menghambat kerja enzim sehingga mempengaruhi proses metabolisme pada serangga. Hollingworth (dalam Utami, Syaufina, \& Haneda, 2010) menjelaskan dalam golongan flavonoid terdapat senyawa rotenon yang berfungsi sebagai toksik pada respirasi sel, dengan cara menghambat transfer elektron dalam NADH-koenzim ubiquinon reduktase (komplek I) dari sistem transpor elektron di dalam mitokondria.

Tanin memiliki sasaran terhadap polipeptida dinding sel yang menyebabkan kerusakan dinding sel, dan mampu pula menggumpalkan protein (Sari, F. P., \& Sari, S. M., 2011). Yunita, Suprapti, dan Hidayat (2009) menambahkan jika tanin memiliki rasa pahit sehingga menghambat serangga untuk memakannya. Ini terjadi karena tanin bereaksi dengan protein membentuk kopolimer mantap yang tidak larut dalam air sehingga protein lebih sukar dicapai oleh cairan pencernaan hewan (Harborne, 1987). Tanin dapat menurunkan aktivitas enzim pencernaan (protease dan amilase) dan mengganggu aktivitas protein usus, sehingga akan mengalami gangguan nutrisi (Aseptianova, 2015).

Saponin dapat merusak mukosa kulit jika terabsorbsi dan akan mengakibatkan hemolisis sel darah sehingga pernapasan menjadi terhambat dan dapat mengakibatkan kematian (Hildamamus, 2004 dalam Liem, 2013). Pengaruh lain yang ditimbulkan oleh saponin terhadap serangga yakni berupa gangguan fisik bagian luar (kutikula). Lapisan lilin yang melindung tubuh serangga dan akan hilang akibat saponin dan menyebabkan kematian karena kehilangan banyak cairan tubuh. Saponin juga menyebabkan aktivitas enzim pencernaan dan penyerapan menurun serta mengganggu proses metabolisme tubuh (Novizan, 2002).

Alkaloid bersifat racun mampu menghambat kerja pada sistem saraf dan merusak membran sel. Golongan ini umumnya akan menghambat enzim asetilkolinesterase, sehingga asetilkolin akan tertimbun pada sinapsis. Efek yang ditimbulkan akan menghambat proses transmisi saraf. Efek lain yang ditimbulkan adalah proses inhibitor sintesis kitin dan kerja hormon yang 
terhambat (Soemirat, 2003). Zat toksik relatif lebih mudah untuk menembus kutikula dan selanjutnya masuk ke dalam tubuh serangga, karena umumnya tubuh serangga berukuran kecil sehingga luas permukaan luar tubuh yang terpapar relatif lebih besar (terhadap volume) (Widyantoro, 2011). Kandungan zatzat inilah yang menyebabkan tanamantanaman secara tidak langsung berpotensi sebagai insektisida alami yang dapat mengganggu bahkan membunuh perkembangan nyamuk Aedes aegypti L.

Menurut Nurdjannah (2004), senyawa linalool yang terkandung pada daun Zodia bersifat racun kontak menyebabkan peningkatan aktifitas saraf sensorik pada serangga. Jika kandungannya lebih besar dapat menyebabkan stimulasi saraf motor sehingga mengakibatkan kejang dan kelumpuhan pada serangga. Linalool merupakan racun kontak yang dapat meningkatkan aktivitas saraf sensorik pada serangga, tepatnya menyebabkan stimulasi saraf motor yang mengakibatkan kejang dan kelumpuhan (Kardinan, 2007).

Berdasarkan hasil penelitian selama 60 menit, diperoleh hasil bahwa nyamuk yang diuji cobakan mengalami kematian dengan tingkat mortalitas yang berbeda untuk setiap ekstrak. Hal ini tentunya dipengaruhi oleh kandungan senyawa yang berbeda pada setiap ekstrak. Ekstrak daun Salam yang diketahui mampu membunuh semua nyamuk yang diuji cobakan memiliki tingkat mortalitas yang tinggi, karena dalam 5 menit semua nyamuk telah mati. Setelah ekstrak daun salam, ada ekstrak daun alpukat yang juga demikian. Kandungan pada ekstrak daun alpukat mampu membunuh semua nyamuk yang diuji cobakan dalam 5 menit. Ekstrak lengkuas jika dilihat dari hasil penelitian, lebih baik dibanding ekstrak mint, meskipun lengkuas dan daun mint sama-sama membunuh nyamuk dalam waktu 10 menit. Lengkuas mampu membunuh nyamuk lebih banyak dibanding daun mint dalam waktu 5 menit. Ekstrak daun Babadotan mampu membunuh nyamuk dalam waktu 20 menit, sedangkan ekstrak Zodia mampu membunuh nyamuk dalam waktu 30 menit (perhitungan menit ke25 dan menit ke-30). Berdasarkan hasil penelitian, dapat disimpulkan urutan ekstrak tanaman dengan kemampuan insektisida paling tinggi sampai dengan rendah adalah: 1) salam, 2) alpukat, 3) lengkuas, 4) mint, 5) babadotan, 6) zodia, dan 7) pucuk merah. Kematian nyamuk diawali dengan kejang-kejang dan kelumpuhan, setelah beberapa menit kemudian, nyamuk dapat dikatakan mati karena sudah tidak ada lagi pergerakan. Hal ini membuktikan adanya kandungan senyawa aktif pada ekstrak yang digunakan, sehingga menyebabkan gangguan metabolisme pada nyamuk. Gangguan metabolisme ini dapat disebabkan melalui proses pernapasan yang kurang sempurna ataupun hormon yang kurang bekerja dengan baik. Gangguan juga terdapat pada sistem saraf nyamuk yang menyebabkan nyamuk menjadi lemas dan tidak dapat bergerak secara aktif.

\section{SIMPULAN, SARAN, DAN REKO- MENDASI}

\section{Simpulan}

Simpulan yang diperoleh dari penelitian adalah semua tanaman yang digunakan efektif terhadap mortalitas nyamuk Aedes aegypti. Secara berurutan tanaman yang paling efektif adalah daun salam, daun alpukat, lengkuas, daun mint, daun babadotan, daun zodia, daun sambiloto, dan daun pucuk merah.

\section{Saran}

Saran yang diberikan terkait penelitian adalah perlunya penelitian lebih lanjut 
mengenai kandungan senyawa aktif yang berperan dalam insektisida pada tanaman yang digunakan.

\section{DAFTAR PUSTAKA}

Adekunle, O. A., \& Ayodele, F. T. (2014). Insecticidal Activity of the Aqueous Leaves Extract of Andrographis paniculata as Protectant of Cowpea Seeds from Callosobruchus maculatus Infestation. Central European Journal of Experimental Biology. 3 (1):29-33.

Admadi H, Bambang. (2009). Mempelajari Bagian Tanaman dan Konsentrasi Ekstrak Kunci Pepet (Kaempferia rotunda L.) yang mempunyai Sifat Repelan Nyamuk Aedes aegypti. Jurnal Agrotekno 15 (2): 43-48.

Aseptianova. (2015). Pemanfaatan Tanaman Sebagai larvasida Alami terhadap Nyamuk Penyebab Demam Berdarah (Aedes aegypti, L.). Palembang; Universitas Muhammadiyah Palembang.

Aseptianova. (2015). Pemanfaatan Berbagai Ekstrak Tanaman sebagai Larvasida Alami. Laporan Penelitian tidak diterbitkan. Palembang: LPPM Universitas Muhammadiyah Palembang.

Boesri, H., Heriyanto, B., Handayani, S. W., \& Suwaryono, T. (2015). Uji Toksisitas Beberapa Ekstrak Tanaman terhadap Larva Aedes Aegypti Vektor Demam Berdarah Dengue. Vektora. 7 (1): 29-38.

Budiasih, Kun Sri. (2011). Pemanfaatan Beberapa Tanaman yang Berpotensi Sebagai Bahan Anti Nyamuk. Artikel. Yogyakarta: Pendidikan Kimia Fakultas MIPA UNY.

Charyadie, F. L., Adi, S., \& Sari, R. P. (2014). Daya Hambat Ekstrak Daun Alpukat (Persea americana, Mill.)
Terhadap Pertumbuhan Enterococcus faecalis. Denta Jurnal Kedokteran Gigi. $8(1)$.

Cushnie T, Lamb AJ. (2005). Antimicrobial activity of flafonoids. International Journal of Antimicrobial Agents. 26: 343-56.

Departemen Kesehatan RI. (1995). Petunjuk Teknis Pemberantasan Penyakit Demam Berdarah. Jakarta: Direktorat Jenderal, PPM \& PLP, Buku Paket B.

Fitriah, S. (2015). Pengaruh Ekstrak Batang Brotowali (Tinospora crispa) terhadap Kematian Larva Nyamuk Aedes aegypti dan Sumbangsihnya pada Mata Pelajaran Biologi di SMA/MA. Skripsi. Palembang: Fakultas Tarbiyah dan Keguruan Universitas Islam Negeri Raden Fatah Palembang.

Harahap, P. S. (20014). Evektivitas Ekstrak Umbi Gadung (Dioscorea hipsida Dents) dalam Pengendalian Larva Nyamuk. Jurnal IPTEKS Terapan. 8 (1).

Harborne, J.B. (1987). Metode Fitokimia: Penuntun Cara Modern Menganalisis Tumbuhan. Bandung: Institut Teknologi Bandung.

Haryati, N. A., Saleh, C., \& Erwin. (2015). Uji Toksisitas dan Aktivitas Antibakteri Ekstrak Daun Merah Tanaman Pucuk Merah (Syzygium myrtifolium walp.) terhadap bakteri Staphylococcus aureus dan Escherichia coli. Jurnal Kimia Mulawarman. 13 (1).

Kardinan, Agus. (2001). Pestisida Nabati Ramuan dan Aplikasi Cetakan ke-3. Jakarta: Penebar Swadaya.

Kardinan, Agus. (2004). Tanaman Pengusir Nyamuk. Tabloid Sinar Tani. www.litbang.deptan.go.id. Diakses tanggal 24 Juli 2016, Pukul 
20.00 WIB.

Kardinan, A. (2007). Tanaman Pengusir dan Pembasmi Nyamuk Edisi Ketiga. Jakarta: Agro Media Pustaka.

Liem, A.F., Holle, E., Gemnafle, I.Y., \& Wakum, S. (2013). Isolasi Senyawa Saponin dari Mangrove Tanjang (Bruguiera gymnorrhiza) dan Pemanfaatannya sebagai Pestisida Nabati pada Larva Nyamuk. Jurnal Biologi Papua. 5 (1): 29-36.

Nofyan, E., Marisa H., dan Kamal M. (2013). Eksplorasi Biolarvasida dari Tumbuhan untuk Pengendalian Larva Nyamuk Aedes aegypti di Sumatera Selatan. Prosiding Semirata FMIPA Universitas Lampung 2013.

Novizan. (2002). Membuat dan Memanfaatkan Pestisida Ramah Lingkungan. Jakarta: Agro Media Pustaka.

Nurdjannah, N., (2004). Diversifikasi Penggunaan Cengkeh. Perspektif, Vol. 3(2), 61-70.

Nuria, M.C., Faizatun. A., dan Sumantri. (2009). Uji Antibakteri Ekstrak Etanol Daun Jarak Pagar (Jatropha cuircas L) terhadap Bakteri Staphylococcus aureus ATCC 25923, Escherichia coli ATCC 25922, dan Salmonella typhi ATCC 1408. Jurnal Ilmu - ilmu Pertanian 5: $26-37$.

Nursal. (2005). Kandungan Senyawa Kimia EkstrakLengkuas (Alpiniagalanga L.) Toksisitas dan Pengaruh Subletalnya terhadapMortalitasLarvaNyamukAedes aegypti. (Online). http://repository. usu.ac.id/bitstream/123456789/ 836/3/06000449.pdf.txt. Diakses tanggal 22 Juli 2016, Pukul 20.00 WIB.

Raini, M. (2009). Toksikologi Insektisida Rumah Tangga dan Pencegahan Keracunan. Media Peneliti dan
Pengembangan Kesehatan XIX.

Rahman, M. S. \& Sofiana, L. (2016). Perbedaan Kerentanan Status Nyamuk Aedes aegypti terhadap Malathion di Kabupaten Bantuk Yogyakarta. Jurnal Kesehatan Masyarakat. 11 (2).

Riyanti. (1996). The effect of lengkuas (Languas galanga (L.) Stuntz) extract to growth of fungi caused skin disease Trichophyton mentgrophytes (Robin) Blancard and Microsporum gypseum (Bodin) Guiart Grigorakis in vitro. Thesis. Bandung: Bandung Institute of Technology.

Sabir A. (2003). Pemanfaatan flavonoid di bidang kedokteran gigi. Majalah Kedokteran Gigi (Dental Journal) Edisi Khusus Temu Ilmiah Nasional. III: 817.

Sari, F.P., \& Sari, S. M. (2011). Ekstraksi Zat Aktif Antimikroba dari Tanaman Yodium (Jatropha multifida Linn) sebagai Bahan Baku Alternatif Antibiotik Alami. Technical Report. Semarang: Universitas Diponegoro.

Sastrohamidjojo, H. (2004). Kimia Minyak Atsiri. Yogyakarta: Universitas Gadjah Mada.

Soemirat, J. (2003). Toksikologi Lingkungan. Yogyakarta: UGM Press.

Utami, S., Syaufina, L., \& Haneda, N. F. (2010). Daya Racun Ekstrak Kasar Daun Bintaro (Cerbera odollam gaertn.) Terhadap larva Spodoptera litura Fabricius. Jurnal Ilmu Pertanian Indonesia 15 (2): 96-100.

Widyantoro, W. (2011). Pengaruh Formulasi The Daun Jambu Biji (Psidium guajava) sebagai Campuran The Terhadap Zona Daya Hambat Mikrobia Anti Diare (Shigella dysenteriae). Yogyakarta: Politeknik Kesehatan. 
Bioeksperimen

Volume 3 No.2, (September 2017)

ISSN 2460-1365

Yunita, E.A., N.H. Suprapti, J.S. Hidayat.

Mortalitas dan Perkembangan Larva (2009). Ekstrak Daun Teklan

Aedes aegypti. Bioma 11 (1): 11-17.

(Eupatorium riparium) terhadap 